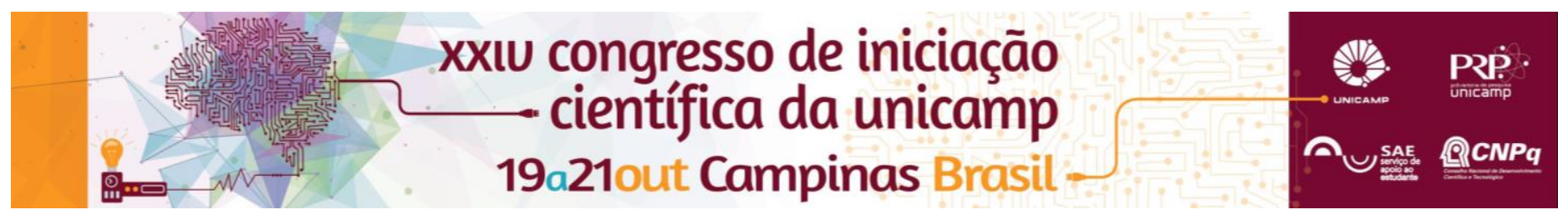

\title{
Datação U-Pb em Badeleíta de rochas vulcânicas máficas da Bacia do Parnaíba ao longo do Lineamento Transbrasiliano
}

\section{Gabriela F. Matheus*, Ticiano J. S. dos Santos, Erica M. Tonetto}

\section{Resumo}

O estudo focalizou a datação de rochas vulcânicas básicas pelo método U-Pb em badeleíta. O método de trabalho compreende as seguintes etapas: (a) revisão bibliográfica da metodologia de datação U-Pb utilizando LA-ICPMS em badeleíta; (b) a preparação das amostras com a separação mineral; (c) comprovação mineral no Microscópio Eletrônico de Varredura (MEV) e (d) obtenção da idade de cristalização das rochas por LA-ICP-MS.

\section{Palavras-chave:}

badeleita, datação U-Pb, LA-ICP-MS

\section{Introdução}

A determinação das idades de cristalização e metamorfismo das rochas é de grande importância para a montagem da evolução tectônica de uma região. A datação por LA-ICP-MS sendo seguido por análise de massa em quadrupolo ou em multicoletor, ainda está em estado de ativo desenvolvimento ${ }^{1}$.

O trabalho tem como principal objetivo possibilitar a familiarização com a metodologia de datação U-Pb e mais especificamente com a utilização de badeleíta em LA-ICP-MS, visando o aprendizado e a observação para a adaptação do método aos equipamentos instalados no Laboratório de Geologia Isotópica do Instituto de Geociências da Unicamp.

Uma das grandes vantagens de se datar por LAICP-MS é o alto rendimento analítico, já que uma análise leva alguns minutos ou menos. Além disso, tem sido amplamente utilizada devido ao reconhecimento da alta e estável intensidade de sinal, considerado de grande importância para alcançar melhor precisão e veracidade nos dados de razão isotópica ${ }^{2}$.

\section{Resultados e Discussão}

Na primeira fase da pesquisa além da revisão bibliográfica foi realizada a preparação das amostras que se iniciou com a britagem, seguido da moagem em um moinho de disco. Após essa preparação, utilizou-se a mesa vibratória (Figura $1 \mathrm{~A}$ ) para realizar a separação por densidade dos minerais e posteriormente foi realizada a catação da badeleíta na lupa binocular Zeiss (Figura 1B).

Nas amostras de basalto do Piauí, TJTb- 47; TJTb- 59B e LTB- 125, esperávamos encontrar badeleíta para obter suas idades de cristalização, porém não se obteve sucesso. O processo de separação na mesa vibratória foi repetido de três formas diferentes, sem sucesso. Visando avaliar o método de separação, usou-se uma amostra de rocha alcalina, em que já se tinha um conhecimento prévio da presença de badeleíta.

Os grãos de badeleíta foram encontrados na amostra do Carbonatito de Jacupiranga e não nas amostras inicialmente estudadas, estes grãos minerais foram confirmados no MEV e puderam passar para a etapa de datação. Este procedimento tem grande relevância porque atesta a eficiência do método no Laboratório de Separação Mineral do IG/UNICAMP.

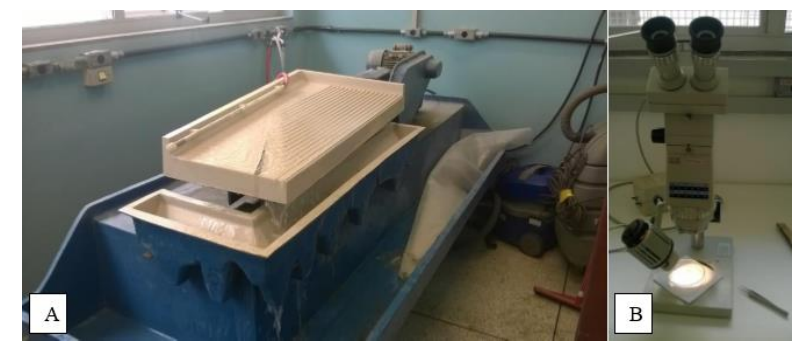

Figura 1. Equipamentos utilizados na separação de badeleíta. A) Mesa vibratória Winfley e B) Lupa binocular Zeiss com aumento de até 63 vezes.

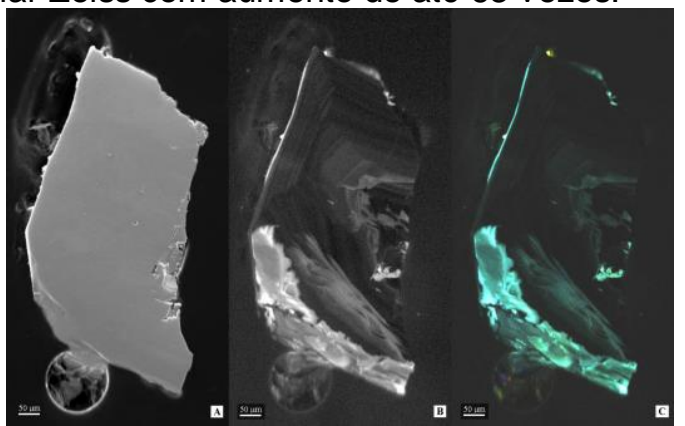

Figura 2: Grãos de Badeleíta A) Imagem EBS. B) Imagem catodoluminescência banda verde. C) Imagem catodoluminescência operação soma.

\section{Conclusões}

O método para separação de badeleíta é eficiente e a amostra inicialmente trabalhada não tem badeleíta em sua constituição, por isso que não se encontrou nos processos realizados. Para o carbonatito de Jacupiranga mounts com badeleíta foram preparados e podem ser datados por LA-ICP-MS.

\section{Agradecimentos}

A pesquisa foi financiada pelo Programa de Bolsas de Iniciação Científica (PIBIC/CNPq), cujo apoio os autores reconhecem e agradecem.

\footnotetext{
Davis, D. W.; Willians, I. S.; Krogh, T. E. Historical development of zircon geochronology, Rev. Mineral. Geochem., v.53, p. 145-181, 2003.

${ }^{2}$ Hirata, T. Advances in Laser Ablation-Multi-Collector Inductively Coupled Plasma Mass Spectrometry. In: VANHAECKE, F. \& DEGRYSE, P., Isotopic Analysis Fundamentals and Applications Using ICP-MS, Germany, Wiley-VCH Verlag \& Co. KGaA, p. 93-112.
} 